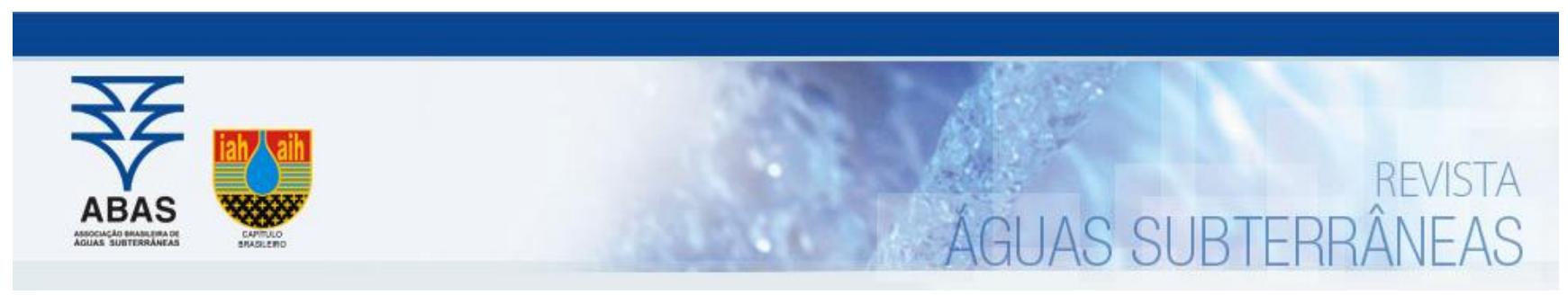

Papers

\title{
Comparison of the inverse modeling approach and traditional methods to estimate the unsaturated hydraulic properties in a sandy loam soil
}

\section{Comparação da abordagem de modelagem inversa e métodos tradicionais para estimar as propriedades hidráulicas insaturadas em solo franco arenoso}

\author{
Leonardo Ezequiel Scherger1,2; Victoria Zanello3; Claudio Lexow ${ }^{1}$ \\ 1 Departamento de Geología, Universidad Nacional del Sur (UNS), Bahía Blanca, Argentina. \\ 2 Consejo Nacional de Investigaciones Científicas y Técnicas (CONICET), CCT Bahía Blanca, Argentina. \\ ${ }^{3}$ Centro de Geología Aplicada, Agua y Medio Ambiente (CGAMA-CIC-UNS). Comisión de Investigaciones Científicas, Bahía Blanca, \\ Argentina.
}

\section{$\underline{\text { leonardo.scherger@uns.edu.ar, victoria.zanello@uns.edu.ar, lexow@uns.edu.ar }}$}

Keywords:

Tension disk infiltrometer Inverse solution.

Soil water retention curve. Hydrus 2D/3D.

\section{Abstract}

The aim of this work is to compare the use of the inverse solution approach in the estimation of soil hydraulic properties with traditional tension disk infiltrometer (TDI) data analysis, field retention data and commonly used pedotransfer functions (PTFs). Field data were collected in an experimental plot located at Bahía Blanca, Argentina. Field infiltration under saturated conditions was measured by the inverse auger hole method and infiltration under unsaturated conditions were carried out with TDI. Field retention data $(\theta(h))$ were also collected periodically. The HYDRUS 2D/3D software was used to optimize soil hydraulic parameters by inverse solution according to TDI data. The saturated hydraulic conductivity measured by inverse auger hole method $\left(5.53 \mathrm{~cm} \cdot \mathrm{h}^{-1}\right)$ and calculated by Wooding analytical approach $(5.35$ $\left.\mathrm{cm} \cdot \mathrm{h}^{-1}\right)$ and inverse numerical simulations $\left(5.36 \mathrm{~cm} \cdot \mathrm{h}^{-1}\right)$ showed very close values. According to macroporosity estimates infiltrated water is mainly conducted through soils micro and mesopores. Macropores only channeled $15.9 \%$ of total infiltrated flow. Soil water retention curves (SWRC) predicted by PTFs did not represented correctly field retention data. The best adjustment between water content at specific pressure heads predicted by SWRCs and field measured water content was reached by the TDI inverse solution approach (RMSE: $0.050 \mathrm{~cm}^{3} . \mathrm{cm}^{-3}$ ). The inverse solution approach probed to be a simple and practical method to obtain an accurate estimate of both, SWRC and hydraulic conductivity curve.

Resumo

Palavras-chave:

Infiltrômetro de disco. Solução inversa.

Curvas de Retenção.

Hydrus 2D/3D.

Peer-reviewed article. Received in: 14/07/2020. Approved in: 20/08/2020.
O objetivo deste trabalho é comparar o uso da solução inversa na estimativa das propriedades hidráulicas do solo com a análise tradicional de dados por infiltrômetro de disco de tensão (IDT), dados de retenção em campo e funções de pedotransferência (FPTs) comumente usadas. Os dados de campo foram coletados em uma parcela experimental localizada em Bahía Blanca, Argentina. A infiltração no campo sob condições satura das foi medida pelo método do furo inverso e a infiltração sob condições insaturadas foi realizada com IDT. Os dados de retenção de campo $(\theta(\mathrm{h}))$ também foram coletados periodicamente. O software HYDRUS 2D/3D foi utilizado para otimizar os parâmetros hidráulicos do solo por solução inversa, de acordo com os dados do IDT. A condutividade hidráulica saturada medida pelo método do furo inverso $\left(5.53 \mathrm{~cm} \cdot \mathrm{h}^{-1}\right)$ e calculada pela abordagem analítica de Wooding $\left(5.35 \mathrm{~cm} \cdot \mathrm{h}^{-1}\right)$ e simulações numéricas inversas $\left(5.36 \mathrm{~cm} . \mathrm{h}^{-1}\right)$ mostraram valores muito próximos. Segundo estimativas de macroporosidade, a água infiltrada é conduzida principalmente através de microporos e mesoporos do solo. Os macroporos canalizaram apenas $15.9 \%$ do fluxo total infiltrado. As curvas de retenção previstas pelos FPTs não representaram corretamente os dados de retenção em campo. 0 melhor ajuste entre o teor de água nas tensões específicas previstas pelas curvas de retenção e o teor de água medido no campo foi alcançado pela abordagem de solução inversa de IDT (RMSE: $0.050 \mathrm{~cm}^{3} \cdot \mathrm{cm}^{-3}$ ). A abordagem de solução inversa demonstrou ser um método simples e prático para obter uma estimativa precisa de curvas de re-tenção e de condutividade hidráulica. 


\section{INTRODUCTION}

Unsaturated soil hydraulic properties estimation is a fundamental requirement to successfully predict water movement in soil. These properties consist of the soil water retention curve (SWRC), which relates the volumetric water content $(\theta)$ to the soil water pressure head $(h)$, and the hydraulic conductivity curve, which relates the conductivity (K) to $\mathrm{h}$ or $\theta$ (Ramos et al., 2006). There are many techniques available to determine soil hydraulic properties, however most of them are time consuming and costly.

The SWRC can be obtained in field by simultaneous measurement of water contents related to different pressure heads at the same soil depth (Rianna et al., 2014; Zhang, 2015; Yan and Zhang, 2015). However, these experiences do not fully represent the SWRC. The main drawbacks are: a) only a very small part of the curve is determined, usually in the range of $0 \geq h>-750$ $\mathrm{cmH}_{2} \mathrm{O}, \mathrm{b}$ ) the method is extremely laborious and requires a large number of measurements and c) hysteresis is very difficult to elucidate, even when working in conditions of desiccation and moistening (Kutilek and Nielsen, 1994). SWRC can also be obtained by laboratory methods, applying the principle of hydrostatic equilibrium. Soil columns are subjected to different hydraulic pressures, determining its volumetric moisture content under each regime. Classical techniques are the sand and sand plus kaolin boxes (Romano et al., 2002), the pressure plate extractor (Dane and Hopmans, 2002a) and the hanging water column method (Dane and Hopmans, 2002b). Evaporation methods (Wind, 1968) allow simultaneous measurement of both, the water retention function and the hydraulic conductivity. Laboratory methods still have certain disadvantages, such as: a) the sample volume may not be representative of the entire soil, $b$ ) the continuity of the poral system may be restricted c) macropores could be destroyed in the sampling procedure and d) each technique is characterized by a resolution range (Bordoni et al., 2017). Therefore, if the SWRC is determined by laboratory techniques, it must be objectively corrected previously it's used in field experiences. Field reconstructed SWRC could represent better the hydrological features of a soil. Generally, response time of changes in hydrological parameters during field meteorological events is faster than variations measured in laboratory controlled conditions (Bordoni et al., 2017).

Among the different procedures developed to estimate soil hydraulic properties, numerical methods involving inverse solution of Richards equation (Simunek and van Genuchten, 1997; Simunek et al., 1998; Ramos et al. 2006; Rashid et al., 2015; Naik et al., 2018; da Silva Junior et al., 2020) are increasingly used. Primal advantage of inverse solution approach is that both, the soil water retention and hydraulic conductivity curves can be estimated simultaneously. The inverse solution comprises a practical method to estimate soil hydraulic parameters when various infiltration tests are carried out under different supply pressure heads. Tension disk infiltrometers (TDI) are devices that have gained popularity in soil hydrology. Through the detailed analysis of TDI data can be derived some soil properties such as saturated hydraulic conductivity, unsaturated hydraulic conductivity (Reynolds and Elrick, 1991; Reynolds et al., 2000), sortivity (AnguloJaramillo et al., 2000), effective porosity (Bodhinayake et al., 2004) and macroporosity estimates (Watson and Luxmoore, 1986). TDI can measure infiltration flux, eliminating the influence of preferential flows that usually occurs under saturated conditions. Thus, it is possible to characterize the conduction capacity of different pore sizes, including active macro and mesopores (Bodhinayake et al., 2004). Simunek and van Genuchten (1997) applying numerical inverse solution approach to multi-tension disk infiltrometry showed that this procedure provides not only information about the saturated hydraulic conductivity, but also of SWRC. For this, it is necessary a combination of cumulative infiltration data for different supplied heads, unsaturated hydraulic conductivities obtained with the Wooding (1968) approach and initial and final water contents for each infiltration test.

Another alternative to estimate the SWRC is based on pedotransfer functions (PTFs). Pedotransfer functions offer an indirect alternative to estimate soil hydraulic properties. In general, PTFs can be defined as methods that predict soil variables that are difficult to measure using correlations with soil attributes that are widely available or can be determined cheaply (Macêdo and Soares, 2020). Various PTFs have been developed, based on different soil properties. Most of them establish a multiple regression analysis between $\theta(h)$ and soil texture, bulk density and organic matter content (Gupta and Larson, 1979; Barros et al., 2013) and in some cases PTFs allow the inclusion of water retention points (Schaap et al., 2001).

In the last years, many works have been published offering comparisons between the inverse solution method and different approaches to estimate soil hydraulic parameters. However, most of them only included direct TDI measurements or laboratory data as comparative results (Ramos et al., 2006; Naik et al., 2018; da Silva Junior et al., 2020). Also, infiltration measurements have been compared with PTFs method for estimating soil hydraulic conductivity (Lee, 2005; Mermound and Xu, 2006; Shein et al., 2015). Nevertheless, there are few examples in the bibliography of comparison between all techniques: field infiltration methods, inverse solution approach, PTFs method and in-situ retention data. As well, it is necessary to adjust these methods to the conditions of filler studied soils.

The aim of this work is to compare the use of inverse solution approach in the estimation of soil hydraulic properties with traditional TDI data analysis, field retention data and commonly used pedotransfer functions. The HYDRUS 2D/3D software (Simunek et al., 2018) was applied to simulate water flow under initial and boundary conditions that reproduced exactly field conditions under which TDI data were obtained. The code was used to optimize soil hydraulic parameters through the inverse solution method.

\section{MATERIALS AND METHODS}

Field measures were made in the industrial complex of Bahía Blanca, Argentina (38 $43^{\circ}$ "S, $62^{\circ} 16^{\prime \prime} \mathrm{W}$ ). Studied area is loca 
ted in the northwest coast of Bahía Blanca Estuary (Fig. 1). The area comprises a marine abrasion platform on which sediments associated with tidal flats are deposited. Natural conditions are only present as restricted relics, since most of the area was highly modified by human activity. Natural soils were covered with filling material to support industrial buildings and roads network. Filler soils are primary composed by compacted sandy loam and loamy sand sediments. They present 1 - 2 meter thickness and normally are enriched in calcium carbonate (Scherger et al., 2019). These materials have given new hydrodynamic properties to topsoil and therefore the unsaturated water flow regime was modified. Kno- wledge of the unsaturated hydrodynamic behavior is essential for an effective management of soil and water resources, particularly in urban or industrial areas. In this environments soil and groundwater pollution is a common fact around the world.

\subsection{Field experiments}

Field retention data $(\theta(h))$ was collected from two sets of tensiometers (SoilMeasurement Corp.) installed at depths of 30, 60 and $90 \mathrm{~cm}$ (Fig. 2a). Volumetric soil water content was simultaneously monitored by gravimetric sampling for the same soil depths (Fig. 2b). Soil characteristics are listed in Table 1.

Figure 1 - Location of study site. Yellow circles show the location of measurements points

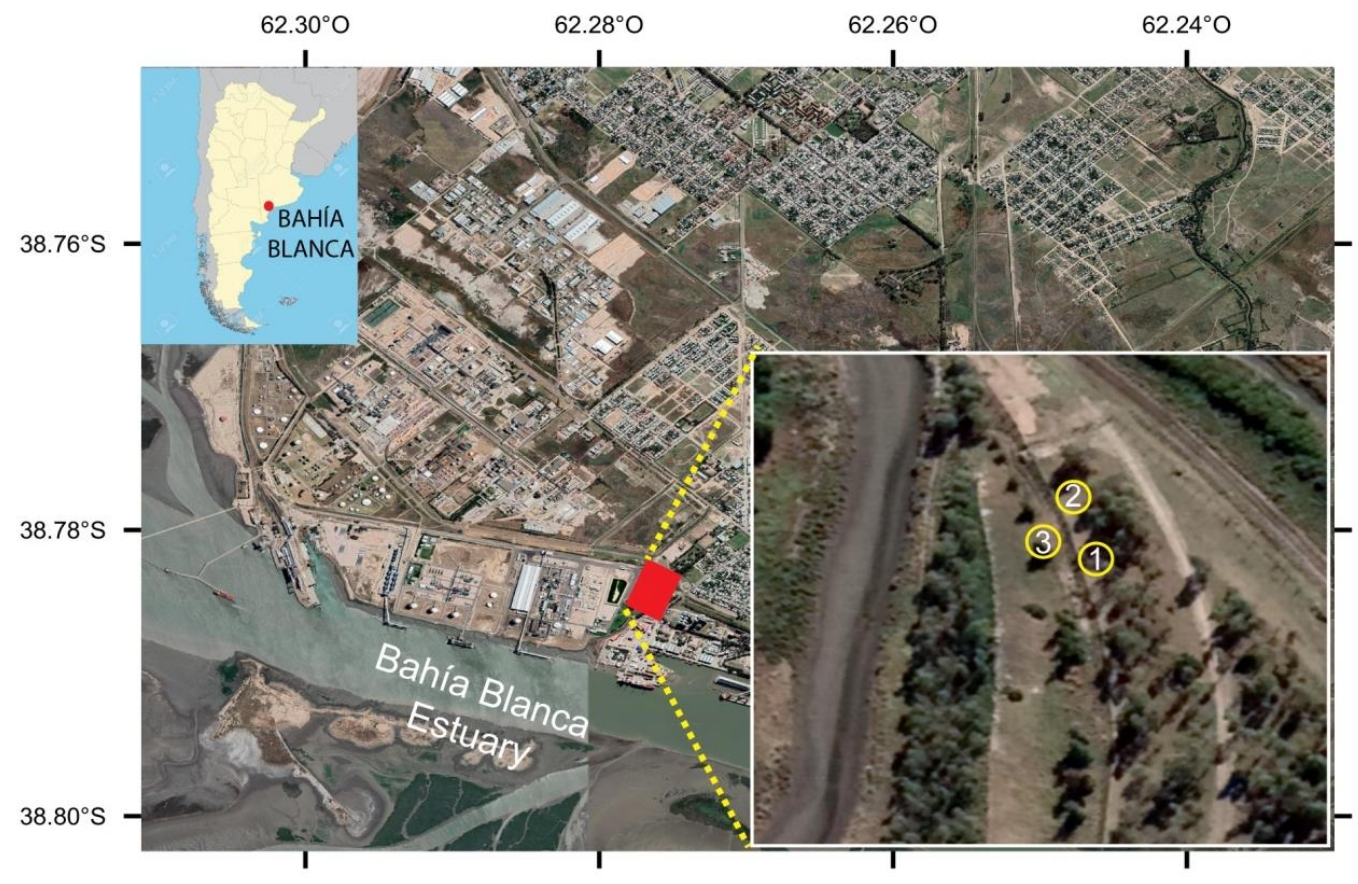

Table 1 - Topsoil properties in the experimental plot

\begin{tabular}{ccccccccc}
\hline Texture Classification & $\begin{array}{c}\text { Sanda } \\
{[\%]}\end{array}$ & $\begin{array}{c}\text { Silta } \\
{[\%]}\end{array}$ & $\begin{array}{c}\text { Clay } \\
{[\%]}\end{array}$ & $\begin{array}{c}\rho_{b^{b}} \\
{\left[\mathrm{~g} \cdot \mathrm{cm}^{-3}\right]}\end{array}$ & $\begin{array}{c}\varphi^{\mathrm{c}} \\
{[-]}\end{array}$ & $\begin{array}{c}\mathrm{CO}_{3}^{-\mathrm{d}} \\
{[\%]}\end{array}$ & $\begin{array}{c}\mathrm{TOCe}^{2} \\
{[\%]}\end{array}$ & $\mathrm{pH}^{\mathrm{f}}$ \\
\hline Sandy loam & 56 & 38 & 6 & 1.41 & 0.46 & 4.8 & 0.2 & 9.5
\end{tabular}

a Pipette method. Grain size distribution: sand $(2.00-0.05 \mathrm{~mm})$, silt $(0.05-0.002 \mathrm{~mm})$ and clay $(<0.002 \mathrm{~mm})$ (Gee and Bauder, 1986). ${ }^{\mathrm{b}} \rho_{\mathrm{b}}$ : Bulk density. Determined by core method (Blake and Hartge, 1986). ${ }^{c} \varphi$ : Total soil porosity. Measured by soil core technique ${ }^{d}$ Direct calcimeter reading (Hulsemann, 1966). e TOC: Total organic carbon. Measured by dry combustion. ${ }^{\mathrm{f}} \mathrm{pH}$ : measured in 1:2.5 soil/water solution.

Field infiltration under saturated conditions was measured by the inverse auger hole method (Ojha et al., 2017). This technique is a quick, simple and reliable method for measuring in-situ saturated hydraulic conductivity of soil. Auger holes of $11 \mathrm{~cm}$ diameter and $35 \mathrm{~cm}$ depth were made in studied soil. Water was repeatedly filled in bore hole for saturating adjoining soil mass of auger holes. When soil saturation was reached, bore holes were re-filled with water and fall in water depths with time were recorded for
30 minutes. Total duration of infiltration tests were three hours due to ensuring soil saturation. Saturated hydraulic conductivity can be calculated as:

$$
K_{S}=1.15 R \frac{\log \left(h\left(t_{0}\right)+\frac{R}{2}\right)-\log \left(h\left(t_{1}\right)+\frac{R}{2}\right)}{t_{1}-t_{0}}=1.15 R \tan \varphi
$$


where $K_{s}$ is the saturated hydraulic conductivity [cm. $h^{-1}$ ], $R$ is the radius of auger hole $[\mathrm{cm}]$ and $h\left(\mathrm{t}_{0}\right)$ and $h\left(\mathrm{t}_{1}\right)$ are the water depth [cm] at initial ( $\left.\mathrm{t}_{0}\right)$ and elapsed time $\left(\mathrm{t}_{1}\right)$ [h], respectively. Graphically, $\log (h(t)+r / 2)$ as a function of elapsed time ( $\left.t_{1}-t_{0}\right)$ can be plotted in order to obtained a straight line. The value of $\varphi$ corresponds to the slope of the line, $y=a x+b$.

Field infiltration under unsaturated conditions was measured with a tension disk infiltrometer (SoilMeasurement Corp.) under negative pressure heads of 3,6 and $15 \mathrm{cmH}_{2} \mathrm{O}$. Measurements must be made supplying three pressure heads, so a better estimate of soil hydraulic properties can be achieved. Each measurement was made in triplicate and infiltration was measured until steady-flow was determined. Initial and final water contents of soil volume beneath the permeable membrane were measured with a time-domain reflectometer (TDR) (SoilMeasurement Corp.) for each infiltration test. Graphic outline of field tasks are illustrated in figure 2c. TDI data were treated according to Wooding's analysis and inverse solution approach.

Figure 2 - Field experiments. a) Set of tensiometers installed at field site. b) Soil sampling by a helicoidally drill. c) Graphic outline of field tests.

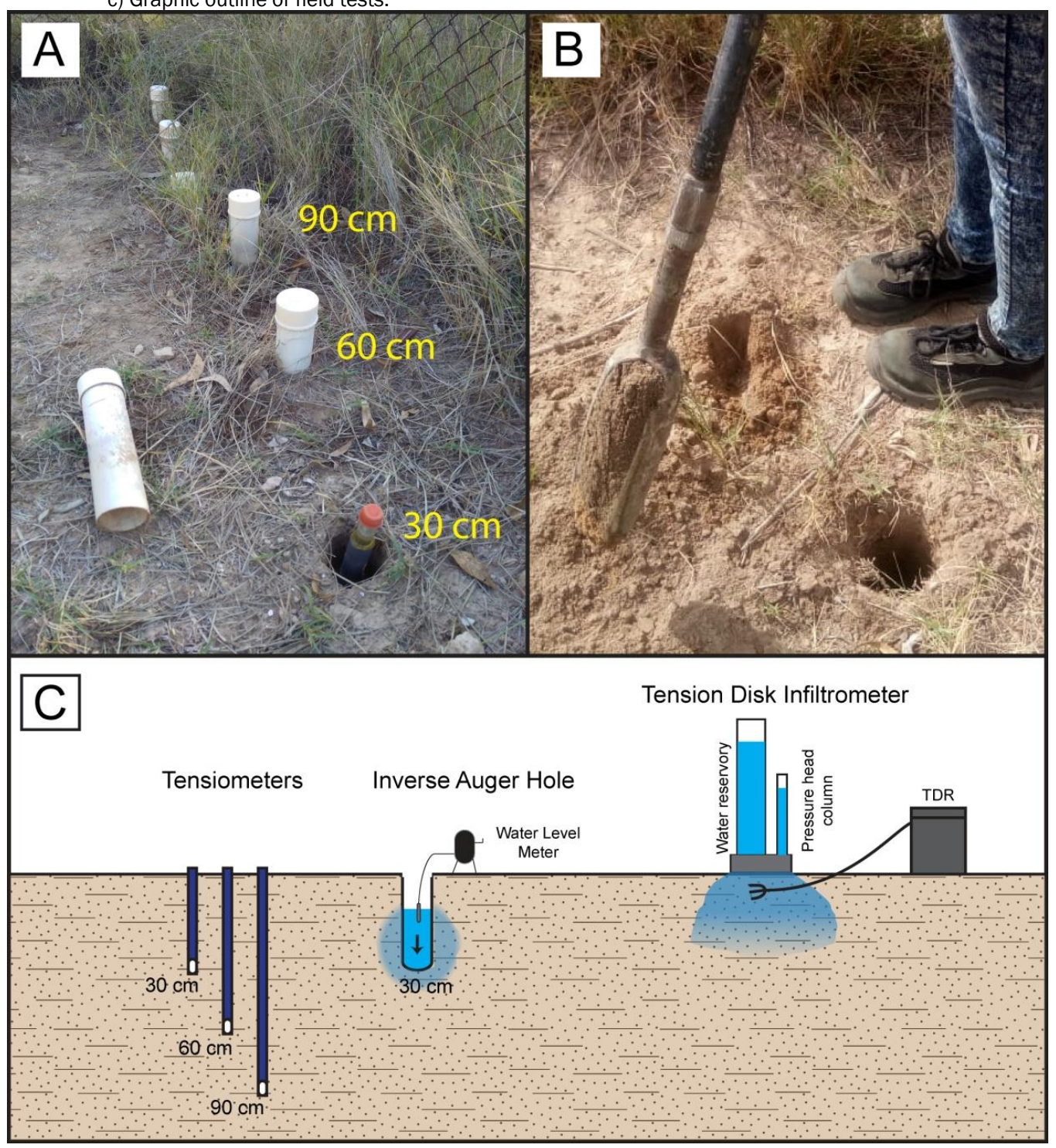




\subsection{Wooding's analytical approach}

Wooding's (1968) analytical solution is the traditional approach to calculate the hydraulic conductivity from tension disk infiltrometer data. Steady-state infiltration rate from a disk can be calculated as:

$Q=\pi r^{2} K\left\{1+\frac{4}{\pi r \alpha}\right\}$

where $Q$ is the steady-state infiltration rate $\left[\mathrm{cm}^{3} \cdot \mathrm{h}^{-1}\right], r$ is the radius of the disk [cm], $\alpha$ is related to the inverse of the air-entry suction $\left[\mathrm{cm}^{-1}\right]$ and $\mathrm{K}$ is the hydraulic conductivity $\left[\mathrm{cm} \cdot \mathrm{h}^{-1}\right]$, given by:

$K(h)=K_{s} \exp (\alpha h)$

where $\mathrm{K}_{\mathrm{s}}$ is the saturated hydraulic conductivity $\left[\mathrm{cm} \cdot \mathrm{h}^{-1}\right]$ and $\mathrm{h}$ is the specific pressure head $\left[\mathrm{CmH}_{2} \mathrm{O}\right]$.

Wooding's analysis requires steady-state infiltration rates at different supply pressure heads. Depending on soil texture, it can take hours or even days to reach steady state in a field experiment (Ramos et al., 2006). Saturated hydraulic conductivity can be calculated from any pair of steady-state infiltration rate corresponding to different supply pressure heads (Ankeny et al., 1991).

\subsection{Effective porosity and macroporosity estimates}

The apparent pore diameter can be calculated using the equation proposed by Watson and Luxmoore (1986):

$\mathrm{r}=-\frac{2 \sigma \cos \gamma}{\rho g h} \cong-\frac{0.15}{\mathrm{~h}}$

where $r$ is the pore radius [cm], $\sigma$ is the water tension surface [g.s2], $\mathrm{y}$ is the contact angle between water and pore wall (it is assumed to be zero), $\rho$ is the water density [g. $\left.\mathrm{cm}^{-3}\right], \mathrm{g}$ is the gravity acceleration [cm.s. $\mathrm{s}^{-2}$ and $\mathrm{h}$ is the applied pressure head $\left[\mathrm{CmH}_{2} \mathrm{O}\right]$. This equation assumes laminar flow and cylindrical pores shapes. Pore size classification proposed by Luxmoore (1981) is adopted, who defines as macro, meso and micropores those that drain at pressure heads greater than $-3 \mathrm{cmH}_{2} \mathrm{O}$, between -3 and -300 $\mathrm{cmH}_{2} \mathrm{O}$ and less than $-300 \mathrm{cmH}_{2} \mathrm{O}$, respectively. Thus, only pores with diameter greater than $1 \mathrm{~mm}$ are considered macropores. The maximum number of effective pores per unit area between radii $\mathrm{a}$ and $\mathrm{b}(\cap(\mathrm{a}, \mathrm{b}))$, being $\mathrm{a}<\mathrm{b}$, can be calculated according to the conjunction of the previous equation and the Poiseuille equation (Watson and Luxmoore, 1986):

$\mathrm{n}_{(\mathrm{a}, \mathrm{b})}=\frac{8 \mathrm{u} \Delta \mathrm{K}_{(\mathrm{a}, \mathrm{b})}}{\pi \rho g\left(\mathrm{r}_{\mathrm{a}}\right)^{4}}$

where $\mu$ is the water viscosity [g.cm-1.s $\mathrm{s}^{-1}$ ], $\Delta \mathrm{K}(\mathrm{a}, \mathrm{b})$ is the hydraulic conductivity for a certain pore range $\left[\mathrm{cm} \cdot \mathrm{h}^{-1}\right]$, and $r_{a}$ is the pore radius $[\mathrm{cm}]$. In the case of pore size ranges, $r_{a}$ value will correspond to the smallest radius in the interval. The smallest pores correspond to those that develop the highest suction (Gómez-Tagle Chávez et al., 2014).The effective porosity $\left[\mathrm{m}^{2} \cdot \mathrm{m}^{-2}\right]$ is equal to:

$\Theta_{\text {effective }}=\cap_{(a, b)} \pi r_{a}{ }^{2}$

The infiltration flow percentage for each pore size range is determined by the ratio:

Infiltration flow $(\%)=\frac{\Delta \mathrm{K}_{\mathrm{i}}}{\mathrm{K}_{\mathrm{s}}} \times 100$

where $\Delta K_{i}=K\left(h_{a}\right)-K\left(h_{b}\right)$ and $h_{a}$ and $h_{b}$ are the specific pressure head for pore sizes with radii $a$ and $b$.

\subsection{Inverse solution approach}

Field infiltration test were simulated by the HYDRUS 2D/3D software (Simunek et al., 2018). The unsaturated water flow is solved by the modified Richards equations, as:

$\frac{\partial \theta}{\partial t}=\frac{\partial}{\partial x_{i}}\left[K\left(K_{i j}^{A} \frac{\partial h}{\partial x_{j}}+K_{i z}^{A}\right)\right]$

where $\theta$ is the volumetric water content $\left[\mathrm{cm}^{3}, \mathrm{~cm}^{-3}\right], \mathrm{h}$ is the pressure head $\left[\mathrm{cmH}_{2} \mathrm{O}\right], \mathrm{x}_{\mathrm{i}-\mathrm{j}}(\mathrm{i}=1,2, . ., \mathrm{n})$ are the spatial coordinates, $\mathrm{t}$ is time [h], $\mathrm{Ka}_{\mathrm{ij}}$ are components of a dimensionless anisotropy tensor and $\mathrm{K}$ is the unsaturated hydraulic conductivity [cm. $\left.\mathrm{h}^{-1}\right]$.

The following constitutive relationships are required to solve $\mathrm{Ri}$ chard's equation. Van Genuchten (1980) proposed such relations as:

Se $=\frac{\theta-\theta_{r}}{\theta_{s}-\theta_{r}}=1+\left[(\alpha h)^{n}\right]^{-m}$

$K\left(S_{e}\right)=K_{S} S_{e}{ }^{l}\left[1-\left(1-S_{e} \frac{1}{m}\right)^{m}\right]^{2}$

where $S_{e}$ is the effective water saturation [-], $\theta_{r}$ is the residual water content $\left[\mathrm{cm}^{3} . \mathrm{cm}^{-3}\right], \theta_{\mathrm{s}}$ is the saturation water content $\left[\mathrm{cm}^{3} \cdot \mathrm{cm}^{-3}\right] . \alpha$ is related to the inverse of the air-entry suction $\left(\mathrm{h}_{\mathrm{a}}\right)$ [cm-1], $\mathrm{h}$ is the pressure head $\left[\mathrm{cmH}_{2} \mathrm{O}\right], \mathrm{n}$ and $\mathrm{m}$ are empirical parameters [-] $\left(m=1-n^{-1}\right) . K_{s}$ is the saturated hydraulic conductivity $\left[\mathrm{cm} \cdot \mathrm{h}^{-1}\right]$ and I is the pore connectivity parameter [-] in the hydraulic conductivity function, estimated to be about 0.5 as an average for many soils (Mualem, 1976).

Water flow was simulated in a 2D rectangle domain of $20 \mathrm{~cm}$ wide and $15 \mathrm{~cm}$ deep. Initial conditions were introduced in terms of volumetric water content, according to initial humidity measured in field for each infiltration test. Top boundary was prescribed as 
a variable pressure head boundary condition whose dimensions are equal to TDI permeable membrane radius. The remaining top nodes and lateral nodes were considered as a no flux boundary condition. The lower boundary was assumed as a free drainage boundary condition (Fig. 3). Simulation time was expressed in minutes, according to the duration of each infiltration test.

Figure 3 - Water flow domain and boundary conditions used in numerical simulation.

\section{TDI diameter}

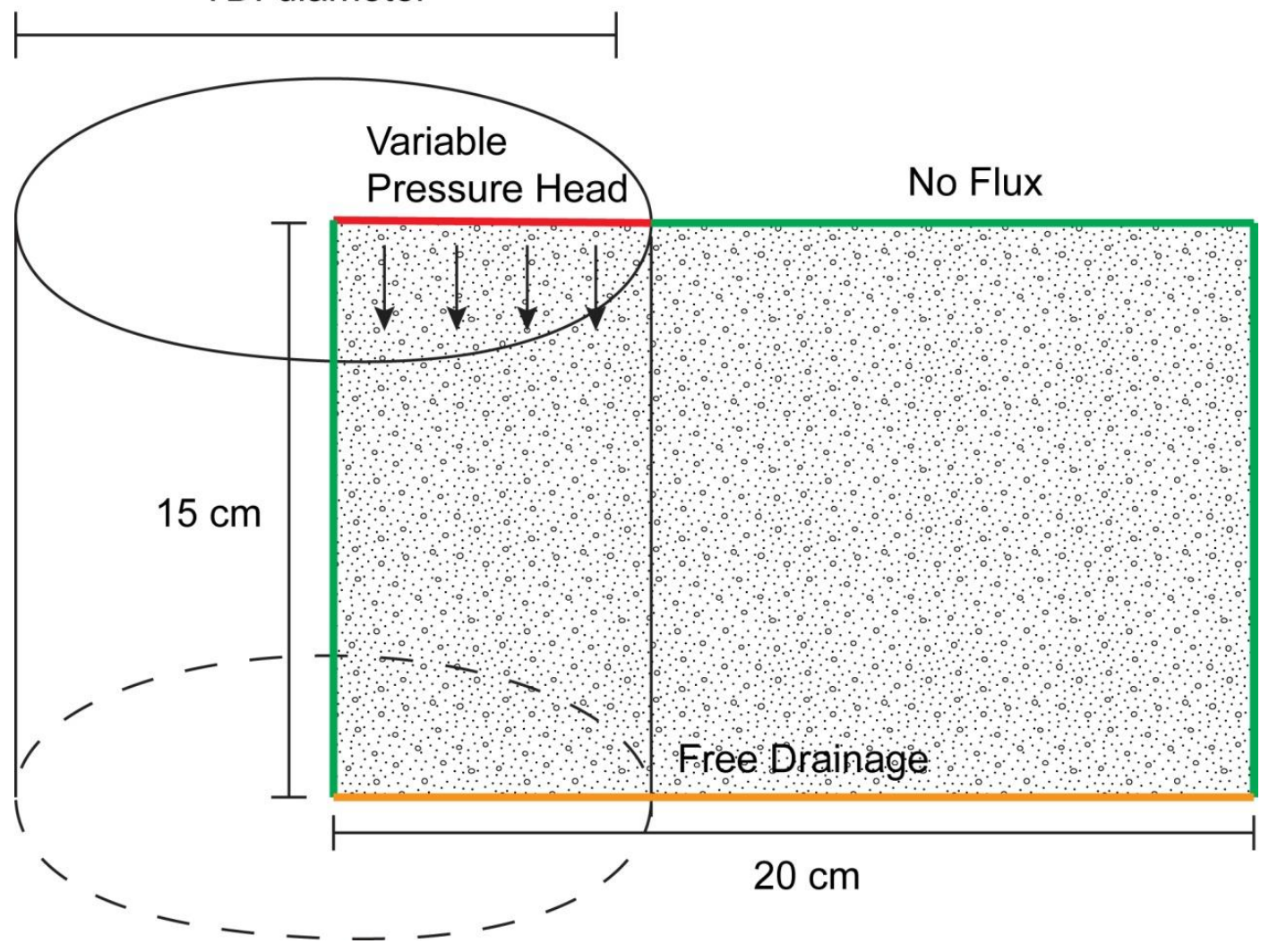

Inverse solution data consisted of cumulate water flux [ $\left.\mathrm{cm}^{3}\right]$ expressed in a time frequency of two minutes and the initial and final volumetric water content for each test. Initial soil hydraulic parameters were estimated according to Wooding analytical approach $\left(\alpha, K_{s}\right)$ and the Rosseta pedotransfer function $\left(\theta_{s}, \theta_{r}, n\right)$
(Schaap et al., 2001) (Table 2). Initial estimates for $\theta_{\mathrm{s}}, \theta_{\mathrm{r}}$ and $\mathrm{n}$ were obtained based on soil texture and bulk density (Table 1). Parameter optimization was carried out for $\theta_{s}, \alpha, K_{s}$ and $n$. These constants are considered as the main factors controlling water flow in the unsaturated zone. 
Table 2 - Initial estimates of soil hydraulic parameters and flow conditions for each simulation.

TEST 1

Initial soil hydraulic parameters

\begin{tabular}{|c|c|c|c|c|c|}
\hline$\theta_{\mathrm{s}}\left[\mathrm{cm}^{3} \cdot \mathrm{cm}^{-3}\right]$ & $\theta_{r}\left[\mathrm{~cm}^{3} \cdot \mathrm{cm}^{-3}\right]$ & $\alpha\left[1 . \mathrm{cm}^{-1}\right]$ & $\mathrm{n}[-]$ & $\begin{array}{c}\mathrm{K}_{\mathrm{s}} \\
{\left[\mathrm{cm} \cdot \mathrm{h}^{-1}\right]}\end{array}$ & 1 \\
\hline 0.4 & 0.035 & 0.0506 & 1.43 & 5.86 & 0.5 \\
\hline \multicolumn{6}{|c|}{ Flow conditions } \\
\hline \multicolumn{2}{|c|}{ Pressure head supplied $\left[\mathrm{cmH}_{2} \mathrm{O}\right]$} & \multicolumn{2}{|c|}{-3} & -6 & -15 \\
\hline \multicolumn{2}{|r|}{ Time [min] } & \multicolumn{2}{|c|}{$0-30$} & $30-54$ & $54-68$ \\
\hline \multirow{2}{*}{\multicolumn{2}{|c|}{$\begin{array}{l}\text { Initial water content } \\
{\left[\mathrm{cm}^{3} \cdot \mathrm{cm}^{-3}\right]}\end{array}$}} & \multicolumn{2}{|c|}{0.12} & $\begin{array}{l}\text { Final water content } \\
\qquad\left[\mathrm{cm}^{3} \cdot \mathrm{cm}^{-3}\right]\end{array}$ & 0.375 \\
\hline & & \multicolumn{2}{|c|}{ TEST 2} & \multicolumn{2}{|c|}{ Initial soil hydraulic parameters } \\
\hline$\theta_{\mathrm{s}}\left[\mathrm{cm}^{3} \cdot \mathrm{cm}^{-3}\right]$ & $\theta_{r}\left[\mathrm{~cm}^{3} \cdot \mathrm{cm}^{-3}\right]$ & $\alpha\left[1 . \mathrm{cm}^{-1}\right]$ & $\mathrm{n}[-]$ & $\begin{array}{c}\mathrm{K}_{\mathrm{s}} \\
{\left[\mathrm{cm} \cdot \mathrm{h}^{-1}\right]}\end{array}$ & 1 \\
\hline 0.4 & 0.035 & 0.0635 & 1.43 & 5.61 & 0.5 \\
\hline \multicolumn{6}{|c|}{ Flow conditions } \\
\hline \multicolumn{2}{|c|}{ Pressure head supplied $\left[\mathrm{cmH}_{2} \mathrm{O}\right]$} & \multicolumn{2}{|c|}{-3} & -6 & -15 \\
\hline & rime [min] & \multicolumn{2}{|c|}{$0-40$} & $40-64$ & $64-98$ \\
\hline \multirow{2}{*}{\multicolumn{2}{|c|}{$\begin{array}{l}\text { Initial water content } \\
{\left[\mathrm{cm}^{3} \cdot \mathrm{cm}^{-3}\right]}\end{array}$}} & \multicolumn{2}{|c|}{0.2} & $\begin{array}{c}\text { Final water content } \\
{\left[\mathrm{cm}^{3} \cdot \mathrm{cm}^{-3}\right]}\end{array}$ & 0.38 \\
\hline & & \multicolumn{2}{|c|}{ TEST 3} & & \\
\hline \multicolumn{6}{|c|}{ Initial soil hydraulic parameters } \\
\hline$\theta_{\mathrm{s}}\left[\mathrm{cm}^{3} \cdot \mathrm{cm}^{-3}\right]$ & $\theta_{r}\left[\mathrm{~cm}^{3} \cdot \mathrm{cm}^{-3}\right]$ & $\alpha\left[1 . \mathrm{cm}^{-1}\right]$ & $\mathrm{n}[-]$ & $\begin{array}{c}\mathrm{K}_{\mathrm{s}} \\
{\left[\mathrm{cm} \cdot \mathrm{h}^{-1}\right]}\end{array}$ & 1 \\
\hline 0.4 & 0.035 & 0.0590 & 1.43 & 4.56 & 0.5 \\
\hline \multicolumn{6}{|c|}{ Flow conditions } \\
\hline \multicolumn{2}{|c|}{ Pressure head supplied $\left[\mathrm{cmH}_{2} \mathrm{O}\right]$} & \multicolumn{2}{|c|}{-3} & -6 & -15 \\
\hline \multicolumn{2}{|r|}{ Time [min] } & \multicolumn{2}{|c|}{$0-32$} & $32-72$ & $72-118$ \\
\hline \multicolumn{2}{|c|}{$\begin{array}{l}\text { Initial water content } \\
{\left[\mathrm{cm}^{3} \cdot \mathrm{cm}^{-3}\right]}\end{array}$} & \multicolumn{2}{|c|}{0.13} & $\begin{array}{c}\text { Final water content } \\
\qquad\left[\mathrm{cm}^{3} \cdot \mathrm{cm}^{-3}\right]\end{array}$ & 0.38 \\
\hline
\end{tabular}

Soil hydraulic parameters optimization by inverse solution is based on the minimization of error between observed and simulated values. User-entered initial estimate are iteratively optimized until the highest possible precision is achieved. Solution is accomplished by the Levenberg-Marquardt method, which it is based on least-squares solution approach (Marquardt, 1963).

\subsection{Pedotransfer functions applied}

To determine van Genuchten hydraulic parameters (Eqn. 9), three types of PTFs were applied. The PTFs based model may be useful when the parameters are computed using easily available soil properties such as texture, bulk density and organic content.

The first PTF applied was proposed by Gupta and Larson (1979), which includes five soil variables:

$$
\begin{gathered}
\theta_{p}=a * \% \text { sand }+ \\
+b * \% \text { silt }+c * \% \text { clay }+d * O M+e \\
* \rho_{b}
\end{gathered}
$$

where $\theta_{p}$ is the predict water content $\left[\mathrm{cm}^{3} \cdot \mathrm{cm}^{-3}\right]$ for a given pressure head and a, b, c, d and e are the regression coefficients that depends on matric potential. OM is the organic matter [\%] and $\rho_{b}$ is the bulk density [g. $\mathrm{cm}^{-3}$ ]. In this case, van Genuchten parameters were adjusted base on $\theta_{p}(\mathrm{~h})$ points obtained from Eqn. 11. Model was developed from the measured SWRC of 43 artificially packed soil cores from ten geographic locations in eastern and central United States.

The second PTF was calculated by Barros et al. (2013). Regression equation was made for tropical soils in northeastern Brazil using water retention data of undisturbed samples. It included four soil variables: content of sand (S) [kg. $\left.\mathrm{kg}^{-1}\right]$, clay (C) [kg. $\left.\mathrm{kg}^{-1}\right]$, organic matter $(0)\left[\mathrm{kg}^{\mathrm{kg}} \mathrm{kg}^{-1}\right]$ and bulk density $\left(\rho_{\mathrm{b}}\right)\left[\mathrm{kg} \cdot \mathrm{m}^{-3}\right]$.

$y_{i}=\beta_{i, 0}+\beta_{i, 1} S+\beta_{i, 2} C+\beta_{i, 3} O+\beta_{i, 4} \rho_{b}+\varepsilon_{i}$

where $\mathrm{y}_{1}$ corresponded to the respective van Genuchten parameters, here treated as PTF response variables: $\alpha=10 \mathrm{y} 1 ; n=y_{2} ; \theta_{r}$ $=y_{3}$ and $\theta_{\mathrm{s}}=y_{4} . \beta_{i, n}$ represented the linear regression coefficients: $\beta_{i, 0}$ the intercept, $\beta_{i, 1}, \beta_{i, 2}, \beta_{i, 3}$ and $\beta_{i, 4}$ are parameters referring to sand, clay, organic matter content and bulk density, respectively. $\varepsilon_{i}$ is the random error associated to each observation.

Last PTF considered was Rosseta (Schaap et al., 2001). This PTF 
was obtained from a large number of soil hydraulic data and soil properties from three databases. Most of the samples were derived from soils in template to subtropical climates of North America and Europe. The data set contained 2134 soil samples for water retention with $20547 \theta(\mathrm{h})$ points. Initially, soil hydraulic parameters were predicted according to soil texture and bulk density. Rosseta also allows the inclusion of water retention points to be used to estimate van Genuchten (1980) parameters. The RECT code (van Genuchten, 1991) was used to optimize initial estimation including field retention data.

\subsection{Statistic validations}

The goodness of fit between field measurements and predicted data is verified using the statistical parameters: coefficient of determination ( $R^{2}$ ) and root mean square error (RMSE). The $R^{2}$ is a statistical measure of how well the regression predictions approximate the real data points, and can be calculated from the following expression:

$$
R^{2}=\frac{S_{(x y)}^{2}}{S_{(x x)}-S_{(y y)}}
$$

where $S(x y)$ is the sum of squares of measured $(X)$ and predicted $(Y)$ values, $S(x x)$ is the sum of squares of $X$ and $S(y y)$ is the sum of squares of Y. A value of 1 obtained from Eqn. (13) indicates a perfect correlation between the fitted and observed values.

The RMSE is the standard deviation of the residuals (prediction errors) and is expressed as:

$$
R M S E=\sqrt{\frac{\sum_{i=1}^{n}\left(P_{i}-O_{i}\right)^{2}}{n}}
$$

where $\mathrm{P}_{\mathrm{i}}$ and $\mathrm{O}_{\mathrm{i}}$ are the predicted and measured values, respectively and $n$ is the number of observations data.

\section{Results and discussion}

\subsection{Inverse auger hole method}

The inverse auger hole method was used to determine in-situ saturated hydraulic conductivity. Fall of water depth with time is shown in figure 4a. Ojha et al. (2017) explain that a linear drop in water depths indicates poor saturated hydraulic conductivity of the soil, as curvilinear drop relates to higher values. The slope of a line plotted between $\log (\mathrm{h}+\mathrm{r} / 2)$ and time can be seen in figure 4b. According to an average slope of 0.000243 and Eqn. (1), $\mathrm{K}_{\mathrm{s}}$ was calculated as $5.53 \mathrm{~cm} \cdot \mathrm{h}^{-1}$.

Figure 4 - Inverse auger hole method results. a) Water depth variation with time in auger hole. b) Variation of $\log (h-r / 2)$ with time
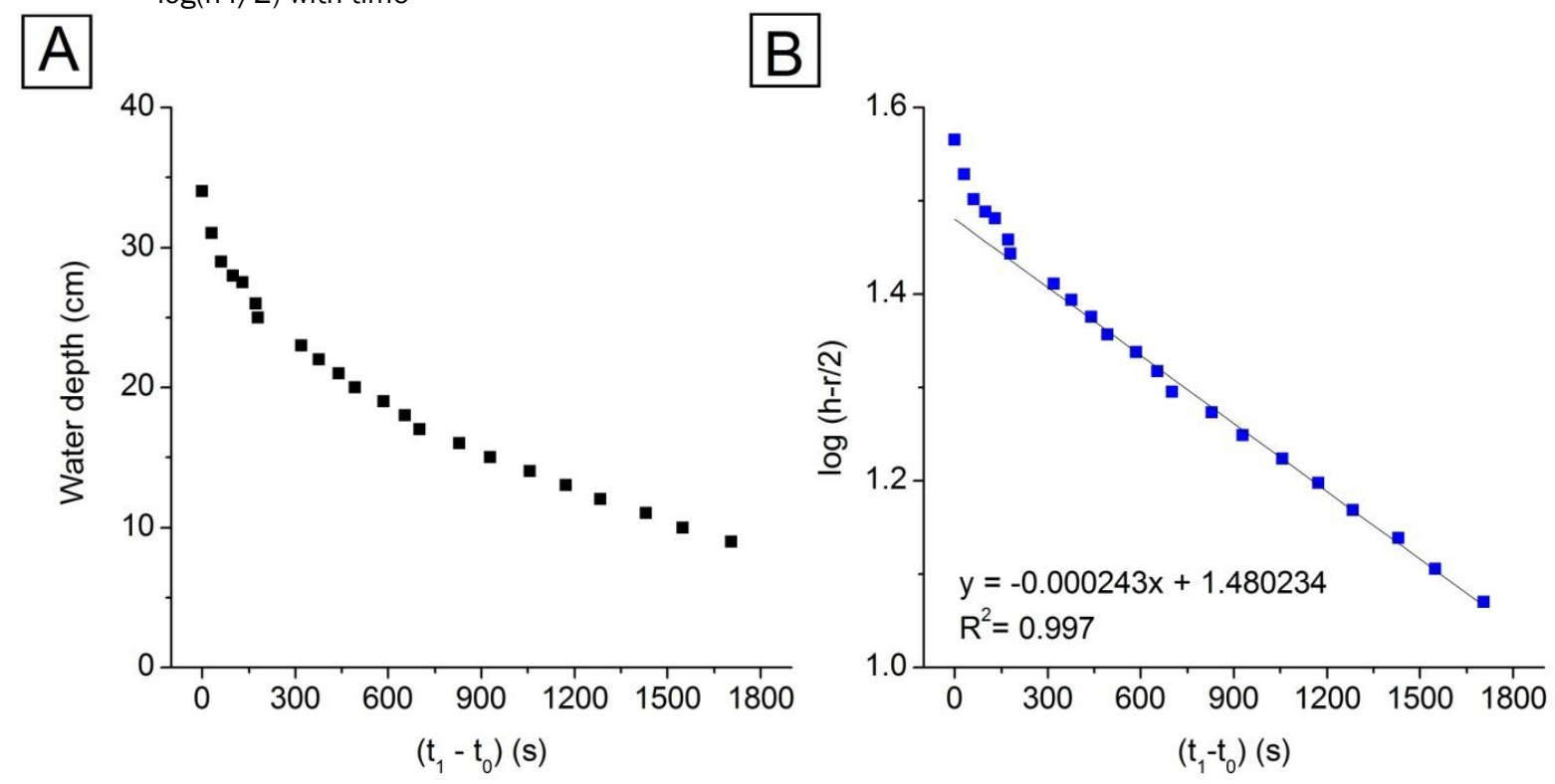

\subsection{Tension disk infiltrometry}

\subsubsection{Wooding's analytical approach}

Hydraulic conductivity is higher at saturated conditions ( $h=0$ $\mathrm{cmH}_{2} \mathrm{O}$ ) and decrease as negative pressure heads increase. This

behavior is observable in figure 5 , where cumulated infiltration over time is shown for infiltration tests under different supplied pressure heads. Slopes of the lines, $y=a x+b$, become smaller as supplied pressure head increase reflecting the participation of smaller pores in the infiltration process. 
Figure 5 - Cumulative infiltration over time for different supplied pressure heads.

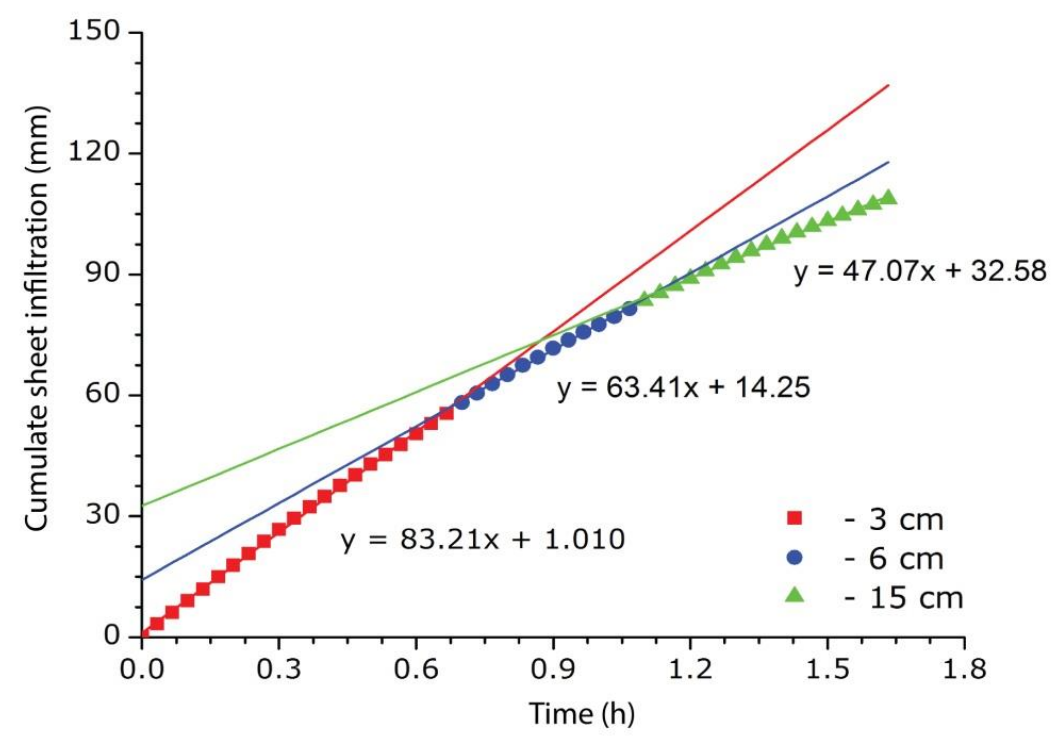

According to Eqn. (2) an average saturated hydraulic conductivity of $5.35 \mathrm{~cm} . \mathrm{h}^{-1}$ was determined for the sandy loam soil. This value is similar to that obtained by the inverse auger hole method. Results from TDI data showed some variability, with standard deviation values of $0.69 \mathrm{~cm} . \mathrm{h}^{-1}$ under saturated conditions. Variability reduced for higher negative pressure heads (Table 3 ). This can be related to macropores shape, which characterized by great dimensional and/or spatial variability in field. Otherwise, when infiltration was measured at higher negative supplied pressure head, water flow is mainly channelized by soil matrix porosity (meso and micropores). These pore size ranges have relatively more homogeneous qualities. The unsaturated hydraulic conductivity was reduced, as pressure head supplied to TDI permeable membrane was increased. When infiltration was measured at a pressure head equal to $-15 \mathrm{~cm} \mathrm{H}_{2} \mathrm{O}$, unsaturated hydraulic conductivity presented lower values than $4 \mathrm{~cm} \cdot \mathrm{h}^{-1}$ in all cases.

Wooding 's approach also allows estimation of parameter $\alpha$ from van Genuchten hydraulic model. This parameter was calculated as $0.05059,0.06354$ and 0.05898 for each infiltration test. Thus, air-entry value can be assumed to be around -15 and -20 $\mathrm{cmH}_{2} \mathrm{O}$.

\begin{tabular}{|c|c|c|c|c|c|c|}
\hline \multicolumn{2}{|c|}{ Test 1} & \multicolumn{2}{|c|}{ Test 2} & \multicolumn{2}{|c|}{ Test 3} & \multirow{2}{*}{ S.D $\left[\mathrm{cm} \cdot \mathrm{h}^{-1}\right]$} \\
\hline $\mathrm{h}\left[\mathrm{cmH}_{2} \mathrm{O}\right]$ & $\mathrm{K}(\mathrm{h})\left[\mathrm{cm} \cdot \mathrm{h}^{-1}\right]$ & $\mathrm{h}\left[\mathrm{cmH}_{2} \mathrm{O}\right]$ & $K(h)\left[\mathrm{cm} \cdot \mathrm{h}^{-1}\right]$ & $\mathrm{h}\left[\mathrm{cmH}_{2} \mathrm{O}\right]$ & $\mathrm{K}(\mathrm{h})\left[\mathrm{cm} \cdot \mathrm{h}^{-1}\right]$ & \\
\hline 0 & 5.87 & 0 & 5.62 & 0 & 4.57 & 0.69 \\
\hline-3 & 5.41 & -3 & 4.99 & -3 & 4.41 & 0.51 \\
\hline-6 & 5.00 & -6 & 4.43 & -6 & 4.25 & 0.39 \\
\hline-15 & 3.93 & -15 & 3.10 & -15 & 3.81 & 0.44 \\
\hline
\end{tabular}

S.D: Standard deviation.

\subsubsection{Effective porosity and macroporosity estimates}

Infiltration was measured in the range of $0<\mathrm{h}<-15 \mathrm{cmH}_{2} \mathrm{O}$. This range comprises pore sizes whose diameter is greater than 0.2 $\mathrm{mm}$. Although this pore size range represents only $3.82 \%$ of total soil volume, approximately $58 \%$ of infiltrated flow is channeled into them (Table 4). Pores with diameters greater than $1 \mathrm{~mm}$ par- ticipate only in $15.9 \%$ of total water flux. Mesopores and micropores channelized the mayor proportion of infiltrated water. This behavior can be attributed to soil compaction, resulting in reduced inter-aggregate structure and macropores destruction. Drainage variability in macropores is associated with soil structure and aggregation, while mesopores and micropores are predominantly related to sediments textural variability. 
Table 4 - Calculated effective porosity for different pore size ranges

\begin{tabular}{|c|c|c|c|c|c|c|}
\hline Pressure head $\left[\mathrm{cmH}_{2} \mathrm{O}\right]$ & $\begin{array}{l}\text { Pore diameter } \\
{[\mathrm{mm}]}\end{array}$ & ก.m² & $\begin{array}{c}\text { Soil volume } \\
{[\%]}\end{array}$ & $\Delta \mathrm{K}_{\mathrm{i}}\left[\mathrm{cm} \cdot \mathrm{h}^{-1}\right]$ & $\begin{array}{c}\mathrm{K}_{\mathrm{s}} \\
{\left[\mathrm{cm} \cdot \mathrm{h}^{-1}\right]}\end{array}$ & Flow percentage [\%] \\
\hline $0-(-3)$ & $>1$ & 984 & 0.08 & 0.85 & - & 15.9 \\
\hline$(-3)-(-6)$ & $1-0.5$ & 13330 & 0.26 & 0.72 & - & 13.4 \\
\hline \multirow[t]{2}{*}{$(-6)-(-15)$} & $0.5-0.2$ & $1.11 \mathrm{E}+6$ & 3.48 & 1.53 & - & 28.7 \\
\hline & $<0.2$ & & & 2.25 & - & 42.1 \\
\hline Total & & & & - & 5.35 & - \\
\hline
\end{tabular}

\subsubsection{Inverse solution approach}

HYDRUS software was used to simulate the infiltrated water flow in field tests. Simulated and observed cumulated infiltrated fluxes $\left[\mathrm{cm}^{3}\right]$ for each field test are shown in figure 6 . For the three simulations, $\mathrm{R}^{2}$ had values higher than 0.98 and $\mathrm{RMSE}$ was lower than $0.04 \mathrm{~cm}^{3} \cdot \mathrm{min}^{-1}$. Inverse solution was used to optimize hydraulic parameters for topsoil. Van Genuchten parameters predicted for each field test are listed in table 5.

Figure 6 - Measured and simulated cumulate infiltration flux for each field test.

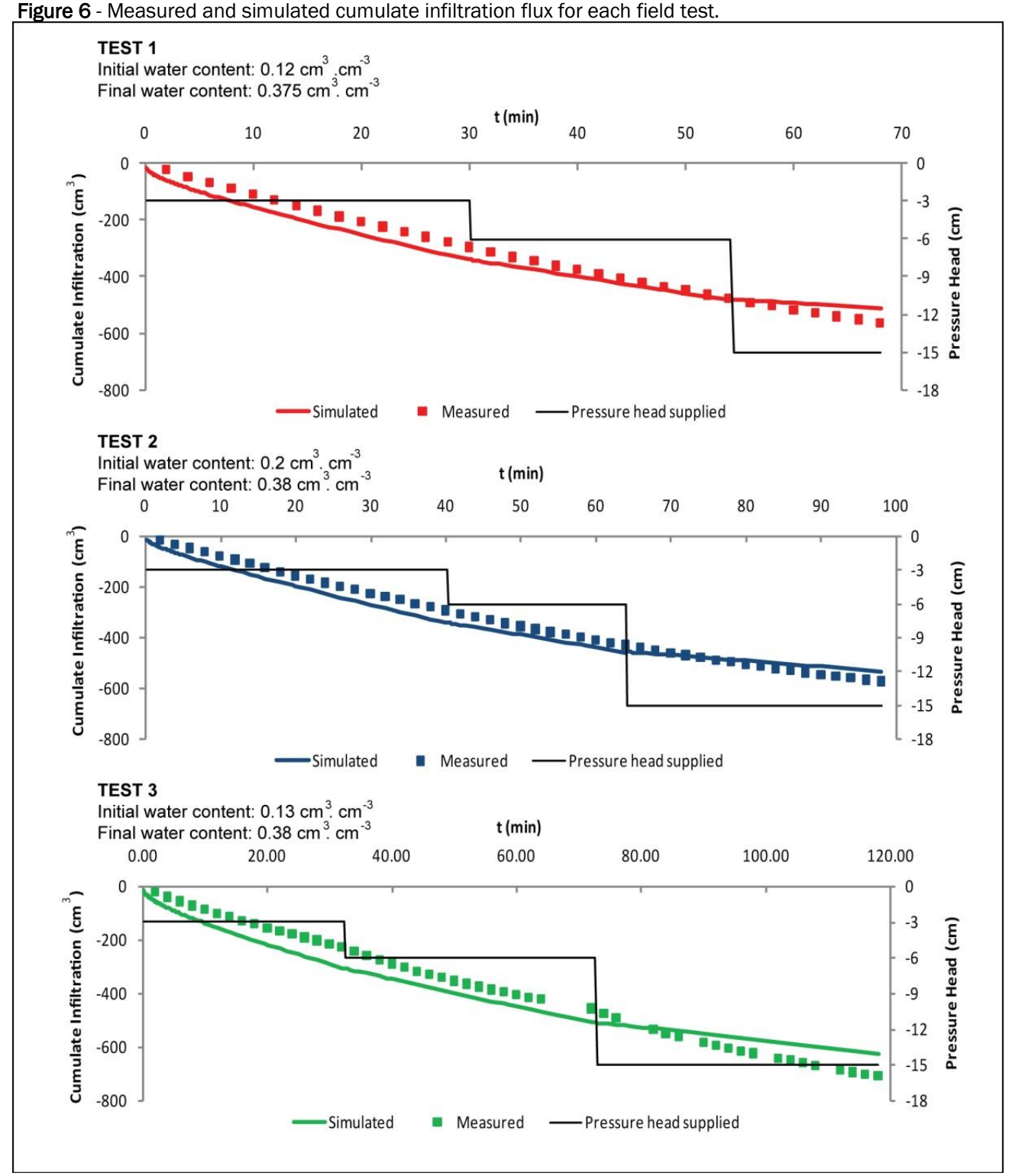


The saturated water content $\left(\theta_{\mathrm{s}}\right)$ was estimated at $0.378 \mathrm{~cm}^{3} . \mathrm{cm}^{-}$ 3 by inverse solution method. This value is similar to final water contents measured at the end of each infiltration tests (range $0.375-0.38 \mathrm{~cm}^{3} . \mathrm{cm}^{-3}$ ). Ramos et al. (2006) showed similar results applying inverse solution approach, where $\theta_{\text {s }}$ agreed closely with values determined using laboratory data and field measurements in loamy soils. Otherwise, estimated $\theta_{\mathrm{s}}$ parameter is lower than total soil porosity measured by soil core technique $(0.46$ $\left.\mathrm{cm}^{3} . \mathrm{cm}^{-3}\right)$. deVos et al. (1999) suggested that the field-saturated water content may be much smaller than the porosity because of entrapped air, the presence of flow irregularities, and deviations from equilibrium flow theory.

Saturated hydraulic conductivity measured by inverse auger hole method and calculated by Wooding analytical approach presented a value of $5.53 \mathrm{~cm} \cdot \mathrm{h}^{-1}$ and $5.35 \mathrm{~cm} \cdot \mathrm{h}^{-1}$ respectively. Similarly, $\mathrm{K}_{\mathrm{s}}$ predicted by inverse solution approach were $5.86 \mathrm{~cm} . \mathrm{h}^{-1}, 5.65$ $\mathrm{cm} \cdot \mathrm{h}^{-1}$ and $4.56 \mathrm{~cm} \cdot \mathrm{h}^{-1}$ for each field infiltration test, with average value being $5.36 \mathrm{~cm} \cdot \mathrm{h}^{-1}$. Results showed great agreement with field measurements.

Table 5 - Soil hydraulic parameters optimized by inverse solution approach

\begin{tabular}{cccccccccc}
\hline & $\theta_{\mathrm{s}}\left[\mathrm{cm}^{3} \cdot \mathrm{cm}^{-3}\right]$ & $\theta_{\mathrm{r}}\left[\mathrm{cm}^{3} \cdot \mathrm{cm}^{-3}\right]$ & $\alpha\left[1 . \mathrm{cm}^{-1}\right]$ & $\mathrm{n}[-]$ & $\mathrm{K}_{\mathrm{s}}\left[\mathrm{cm} \cdot \mathrm{h}^{-1}\right]$ & $\mathrm{I}$ & $\mathrm{R}^{2}$ & $\mathrm{RMSE}\left[\mathrm{cm}^{3} \cdot \mathrm{min}^{-1}\right]$ \\
\hline Test 1 & 0.380 & 0.035 & 0.0392 & 1.3843 & 5.86 & 0.5 & 0.991 & 0.037 \\
Test 2 & 0.375 & 0.035 & 0.0336 & 1.3061 & 5.65 & 0.5 & 0.992 & 0.029 \\
Test 3 & 0.380 & 0.035 & 0.0300 & 1.3065 & 4.56 & 0.5 & 0.982 & 0.037 \\
Average & 0.378 & 0.035 & 0.0343 & 1.3323 & 5.36 & 0.5 & & \\
\hline
\end{tabular}

Contrary, parameter $\alpha$ predicted by inverse solution is lower than the value calculated according to Wooding's approach. In this case, parameter $\alpha$ had an average value of 0.0343 . Consequently, air-entry value will be equal to $-29 \mathrm{cmH}_{2} \mathrm{O}$. This phenomenon may be due to the fact that simulation did not consider hysteresis phenomenon as shown in many works (Kool and Parker, 1987; Likos et al., 2014; Bordoni et al., 2017). As field infiltration was measured for the wetting branch of the SWRC, there could be some discrepancies between $\alpha$ value predicted by model simulations and field data. When passing from wetting to drying conditions, a decrease in $\alpha$ fitting parameter is highlighted.

\subsection{Determination of soil hydraulic parameters by pedotransfer functions}

SWRC was also estimated according to three different PTFs. Van Genuchten parameters for each PTF are listed in table 6. Residual and saturated water content vary according to PTF used from $0.034 \mathrm{~cm}^{3} \cdot \mathrm{cm}^{-3}$ to $0.098 \mathrm{~cm}^{3} \cdot \mathrm{cm}^{-3}$ and $0.369 \mathrm{~cm}^{3} \cdot \mathrm{cm}^{-3}$ to $0.468 \mathrm{~cm}^{3} . \mathrm{cm}^{-3}$, respectively. Values obtained from Rosseta-PTF (III-IV) are very close to those reached by inverse solution approach. Contrary, PTF (I) overestimated the residual water content and PTF (II) overestimated the saturated water content. Parameter $\alpha$ ranged from 0.011 to $0.126 \mathrm{~cm}^{-1}$ and parameter $\mathrm{n}$ ranged from 1.388 to 1.715. Values obtained from PTFs (I) and (II) differ more than Rosseta-PTF (III-IV) from parameters optimized by inverse solution approach. Pachepsky and Rawls (2004) recommended the use of PTFs for regions or soil types similar to those in which they were developed. PTF (I) was developed for specific soils of the United States while PTF (II) was created for soils of tropical climates. Since the edaphic properties of such soils could be vastly different from studied soil, discrepancies are expected. Otherwise, Rosseta-PTF is based on a much larger soil catalogue than the others two PTF applied.

Table 6 - van Genuchten parameters based on PTFs applied

\begin{tabular}{ccccc} 
PTF & $\theta_{\mathrm{r}}\left[\mathrm{cm}^{3} . \mathrm{cm}^{-3}\right]$ & $\theta_{\mathrm{s}}\left[\mathrm{cm}^{3} . \mathrm{cm}^{-3}\right]$ & $\alpha\left[1 . \mathrm{cm}^{-1}\right]$ & $\mathrm{n}[-]$ \\
\hline I & & & & \\
\hline II & 0.098 & 0.400 & 0.0114 & 1.525 \\
III & 0.057 & 0.468 & 0.1264 & 1.715 \\
IV & 0.034 & 0.369 & 0.0208 & 1.444 \\
\hline
\end{tabular}

I: Gupta and Larson (1979). II: Barros et al. (2013). III: Rosseta-Schaap et al. (2001). IV: Rosseta optimized. 


\subsection{Soil water retention and hydraulic conductivity curves com- parisons}

SWRCs estimated by inverse solution for each TDI test are presented in figure $7 \mathrm{a}$ and SWRCs predicted by PTFs are shown in figure $7 \mathrm{~b}$. SWRCs are compared with field retention data $(\theta(\mathrm{h}))$ ( $n=60$ observation points). Agreement between water content at specific pressure heads predicted by SWRCs and measured water content was quantified by the RMSE. The best adjust was achieved by the inverse solution approach (RMSE $\left.=0.050 \mathrm{~cm}^{3} . \mathrm{cm}^{-3}\right)$.
It is follow by the Rosseta-PTF, when field retention data was incorporated in the objective function (RMSE $\left.=0.092 \mathrm{~cm}^{3} . \mathrm{cm}^{-3}\right) . \mathrm{Si}-$ milar results were obtained when SWRC was predicted by Rosseta-PTF (RMSE $=0.093 \mathrm{~cm}^{3} . \mathrm{cm}^{-3}$ ) and Gupta and Larson-PTF (RMSE $=0.094 \mathrm{~cm}^{3} . \mathrm{cm}^{-3}$ ) using texture and bulk density data. The worst adjustment was made by Barros et al.-PTF (RMSE: 0.226 $\left.\mathrm{cm}^{3} \cdot \mathrm{cm}^{-3}\right)$. Parameters $\theta_{\mathrm{s}}, \alpha$ and $\mathrm{n}$ predicted by this PTF differed greatly from values optimized by the inverse solution approach.

Figure 7 - SWRC estimations comparison. a) SWRCs estimated by inverse solution approach. b) SWRCs predicted by PTFs and TDI inverse solution

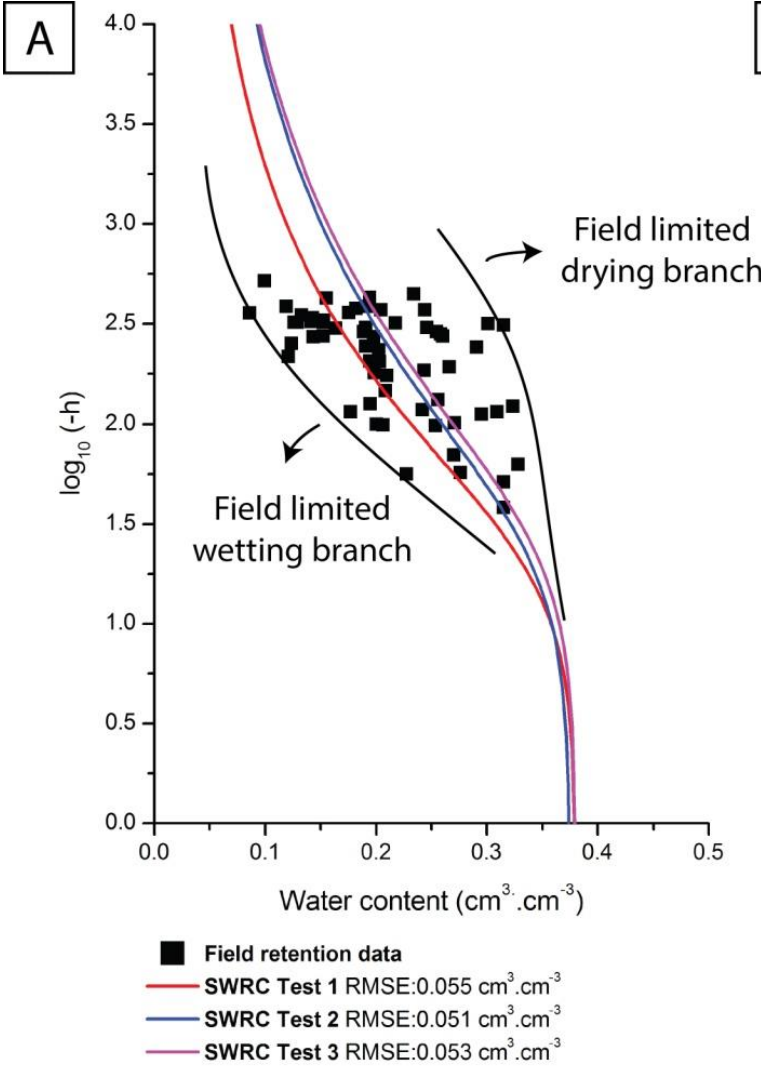

In figure $7 a$, it can be seen that SWRCs represent three curves of the SWRCs family. Accordingly, TDI estimated curves are limited by both field retention curves, the wetting and drying branches. Since SWRC laboratory retention point are not available, the SWRC obtained from field methodologies present their validity range under the pressure head range of $0>\mathrm{h}>-800 \mathrm{cmH}_{2} \mathrm{O}$ only. It is necessary to appeal to laboratory practices when determinations are needed for higher hydraulic pressures. Rashid et al. (2015) propose the incorporation of independent retention data

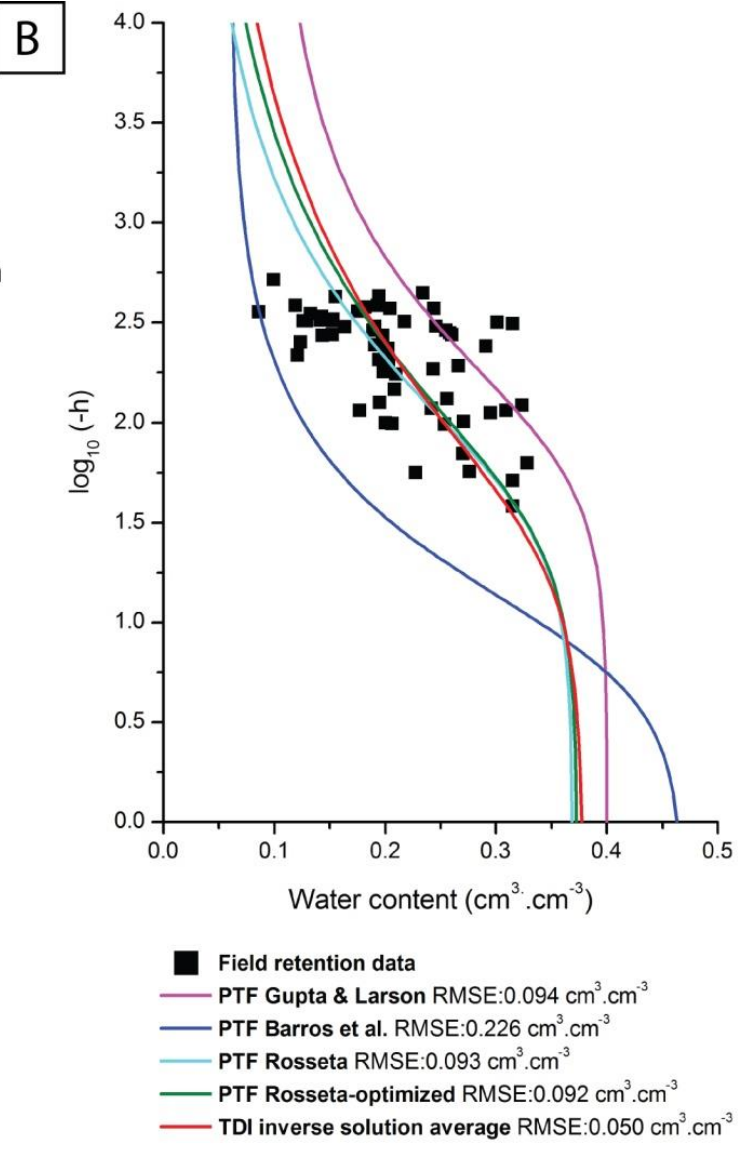

for high values of pressure head (e.g.: $-15000 \mathrm{cmH}_{2} \mathrm{O}$ ), especially to define the dry branch of the SWRC. Similarly, Ramos et al. (2006) indicated that the main limitation of the inverse solution method is the dependence on the water contents field measurement. Given the spatial variability, some problems may arise related to the correct determination of initial water content in soil. These effects are reduced when water contents at -100 and $15000 \mathrm{cmH}_{2} \mathrm{O}$ were incorporated into the objective function. 
Hydraulic conductivity curves estimated by Wooding 's analytical method and inverse solution approach are shown in figure 8. Unlike $K_{s}$ value for the sandy loam soil predicted by both methods is very similar, there are some discrepancies between $\mathrm{K}(\mathrm{h})$ function when negative pressure heads increase. Several studies have shown that Wooding's approach tends to overestimate the hydraulic conductivity if steady-state infiltration is not reached (Bagarello et al., 2000). Nevertheless, possible error is usually dismissed as being negligible relative to errors related to soil heterogeneity or lack of reproducibility of the infiltration experimen- ts (Ramos et al., 2006). When comparing field measurements variability between both methods, it can be seen that field uncertainties prevail in the suction range close to saturation $(\mathrm{h}>-0.1$ $\mathrm{cmH}_{2} \mathrm{O}$ ). Under this condition, fill area representing variability in the infiltrations tests overlaps as the hydraulic conductivity increase (Fig. 8). However, under unsaturated conditions of greater interest $\left(\mathrm{h}<-0.1 \mathrm{cmH}_{2} \mathrm{O}\right.$ ) discrepancies related to field heterogeneities lose importance with respect to the variability related to each approach.

Figure 8 - Unsaturated hydraulic conductivity curve. Fill area represents measurements

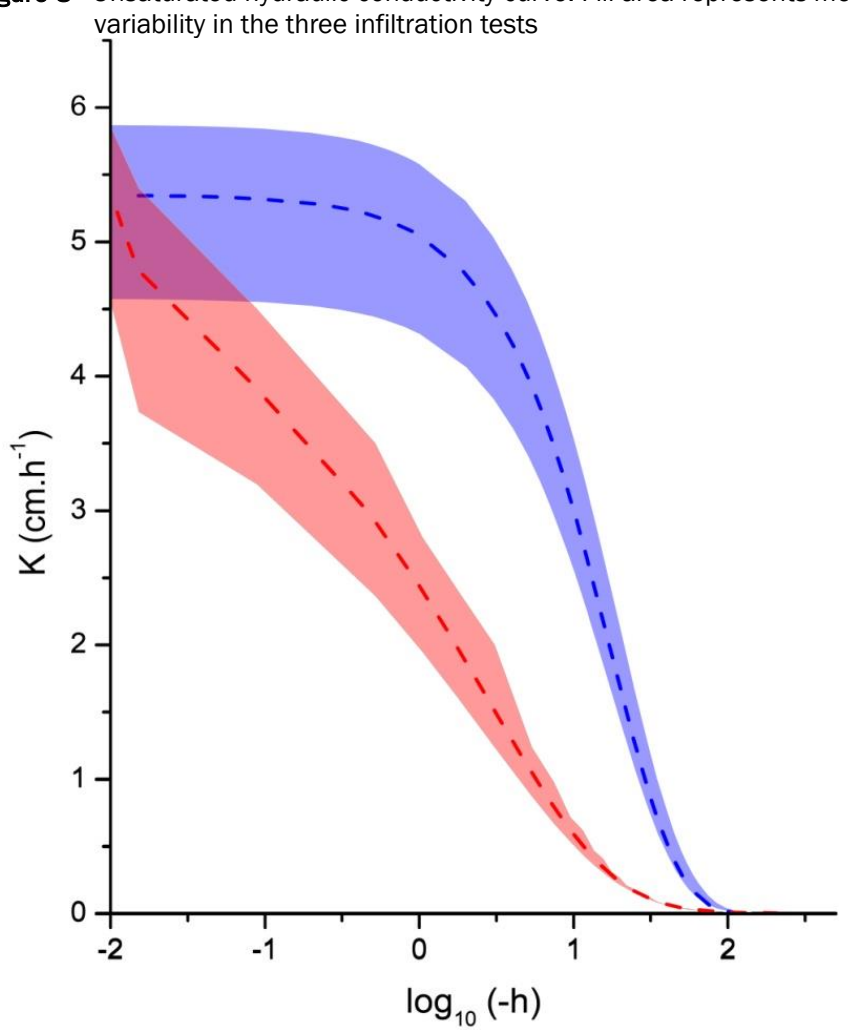

- - - Wooding's approach

- - - Inverse solution approach

\section{CONCLUSIONS}

- $\quad$ The use of TDI data in soil hydraulic parameters determination by inverse solution approach probed to be a simple and practical method to obtain an accurate estimate of both, SWRC and $\mathrm{K}(\mathrm{h})$.

- $\quad$ The saturated hydraulic conductivity measured by inverse auger hole method $\left(5.53 \mathrm{~cm} . \mathrm{h}^{-1}\right)$ and calculated by Wooding analytical approach $\left(5.35 \mathrm{~cm} \cdot \mathrm{h}^{-1}\right)$ and inverse numerical simulations $\left(5.36 \mathrm{~cm} . \mathrm{h}^{-1}\right)$ showed very close values.

- $\quad$ According to TDI data mesopores and micropores channelized the mayor proportion of infiltrated water. Macropores only participate in $15.9 \%$ of total water flux.

- $\quad$ SWRCs predicted by PTFs did not correctly represented field retention data. The best adjustment between water content at specific pressure heads predicted by SWRCs and field measured water content was reached by the TDI inverse solution approach (RMSE: $0.050 \mathrm{~cm}^{3} . \mathrm{cm}^{-3}$ ).

- Unsaturated conductivity curve showed discrepancies between values calculated by Wooding's and inverse solution approach.

\section{REFERENCES}

ANGULO-JARAMILLO, R., VANDERVAERE, J. P., ROULIER, S., THONY, J. L., GAUDET, J. P.; VAUCLIN, M. Field measurement of soil surface hydraulic properties by disc and ring infiltrometers: A review and recent developments. Soil and Tillage Research, v. 
55, p. 1-29, 2000. https://doi.org/10.1016/S01671987(00)00098-2

ANKENY, M. D., AHMED, M., KASPAR, T. C.; HORTON, R. Simple Field Method for Determining Unsaturated Hydraulic Conductivity. Soil Science Society of America Journal, v.55, p. 467-470, 1991.

https://doi.org/10.2136/sssaj1991.036159950055000200 $\underline{28 x}$

BAGARELLO, V., IOVINO, M.; TUSA, G. Factors affecting measurement of the near-saturated soil hydraulic conductivity. Soil Science Society of America Journal, v.64, p. 1203-1210, 2000. https://doi.org/10.2136/sssaj2000.6441203x

BARROS, A., LIER, Q., MAIA, A.; SCARPARE, F. V. Pedotransfer functions to estimate water retention parameters of soils in northeastern Brazil. Revista Brasileira de Ciência do Solo, v.37, n.2, 379-391, 2013. https://doi.org/10.1590/S0100$\underline{06832013000200009}$

BLAKE, G.R.; HARTGE, K.H. Bulk density. In: KLUTE, A., Ed., Methods of Soil Analysis, Part 1-Physical and Mineralogical Methods, 2nd Edition, Agronomy Monograph 9, American Society of Agronomy-Soil Science Society of America, Madison, p.363382, 1986.

BODHINAYAKE, W., SI, B. C.; XIAO, C. New method for determining (water conducting) macro and mesoporosity from tension infiltrometer. Soil Science Society of America Journal, v.68, p. 760-769, 2004. https://doi.org/10.2136/sssaj2004.7600

BORDONI, M., BITTELLI, M., VALENTINO, R., CHERSICH, S.; MEISINA, C. Improving the estimation of complete field soil water characteristic curves through field monitoring data. Journal of Hydrology, v.552, p. 283-305, 2017. http://dx.doi.org/10.1016/i.jhydrol.2017.07.004

DANE, J.H.; HOPMANS, J.W. Pressure plate extractor. In: DANE, J.H.; TOPP, G.C (eds). Methods of soil analysis. Part 4. Physical methods. SSSA Book Ser. 5. SSSA, Madison, WI. p. 688-690, $2002 a$.

DANE, J.H.; HOPMANS, J.W. Hanging water column. In: DANE, J.H.; TOPP, G.C (eds). Methods of soil analysis. Part 4. Physical methods. SSSA Book Ser. 5. SSSA, Madison, WI. p. 680-683, 2002b.

DA SILVA JUNIOR, J.J., COLOMBO, A., OLIVEIRA, G.C., SILVA, B. ; JULIACI EUGÊNIO, J. Estimation of tropical soils' hydraulic properties with inverse method and tension infiltrometer field data. Ambiente \& Água, v.15, n. 3, p. 1-15, 2020. https://doi.org/10.4136/ambi-agua.2503

DE VOS, J.A., SIMUNEK, J., RAATS, P.A.C.; FEDDES, R.A. Identification of the hydraulic characteristics of a layered silty loam. In: VAN GENUCHTEN, M.T. et al.(ed). Characterization and measurement of the hydraulic properties of unsaturated porous media. Univ. of California, Riverside, p. 783-798, 1999.
GEE, G.W.; BAUDER, J.W. Particle-size analysis. In: KLUTE, A. (ed) Methods of soil analysis. Part 1. Physical and mineralogical methods. American Society of Agronomy and Soil Science Society of America, Madison, p.399-403, 1986.

GÓMEZ-TAGLE, A., GEISSERT, D.; ENRÍQUEZ-FERNÁNDEZ, E. Manual de infiltrometría: Infiltrómetro de tension INDI. Instituto de Ecología, A.C., Xalapa, Veracruz, 2014.

GUPTA, S.; LARSON, W. E. Estimating soil water retention characteristics from particle size distribution, organic matter percent, and bulk density. Water resources research, v. 15, n. 6, p. 1633-1635, 1979. https://doi.org/10.1029/WR015i006p01633

HULSEMAN, J. An inventory of marine carbonate materials. Journal of Sedimentary Petrology, v.36, p.622-625, 1966.

KOOL, J.B.; PARKER, J.C. Development and evaluation of closedform expressions for hysteretic soil hydraulic properties. Water Resources Research, v.23, n. 1, p.105-114, 1987. https://doi.org/10.1029/WR023i001p00105

KUTILEK, M.; NIELSEN, D.R. Soil hydrology. Catena Verlag, Cremlingen-Destedt, Germany. 370 pp, 1994.

LEE, D.H. Comparing the inverse parameter estimation approach with pedo-transfer function method for estimating soil hydraulic conductivity. Geosciences Journal, v. 9, n. 3, p. 269 276, 2005. . https://doi.org/10.1007/BF02910587

LIKOS, W.J., LU, N.; GODT, J.W. Hysteresis and uncertainty in soil-water retention curve parameters. Journal of Geotechnical \& Geoenvironmental Engineering, v.140, n.4, p.04013050, $2014 . \quad$ https://doi.org/10.1061/(ASCE)GT.1943-

5606.0001071

LUXMOORE, R. J. Micro, Meso and Macroporosity of Soil. Soil Science Society of America Journal, v.45, n. 3, p. 671-672, 1981.

https://doi.org/10.2136/sssaj1981.036159950045000300 $\underline{51 x}$

MACÊDO, G.; SOARES, W. Utilização de métodos de campo e laboratoriais para estimação de propriedades hidrodinâmicas do solo. Águas Subterrâneas, v. 34, n. 2, p. 166-176, 2020. https://doi.org/10.14295/ras.v34i2.29809

MARQUARDT, D. W. An algorithm for least-squares estimation of nonlinear parameters. Journal of the Society for Industrial and Applied Mathematics, v.11, n. 2, p. 431-441, 1963. https://doi.org/10.1137/0111030

MERMOUD, A.; XU, D. Comparative analysis of three methods to generate soil hydraulic functions. Soil \& Tillage Research, v. 87, p. 89-100, 2006. https://doi.org/10.1016/j.still.2005.02.034

MUALEM, Y. A new model for predicting the hydraulic conductivity of unsaturated porous media. Water Resources Research, v.12, n.3, p. 513-522, 1976. https://doi.org/10.1029/WR012i003p00513 
NAIK, A. P., GHOSH, B.; PEKKAT, S. Estimating soil hydraulic properties using mini disk infiltrometer. ISH Journal of Hydraulic Engineering, v. 25, n. 1, p. 2164-3040, 2018. https://doi.org/10.1080/09715010.2018.1471363

OHJA, R.P., VERMA, C.L., DENIS, D.M., SINGH, C.S.; KUMAR, M. Modification of inverse auger hole method for saturated hydraulic conductivity measurement. Journal of Soil and Water Conservation, v.16, n.1, p. 47-52, 2017. https://doi.org/10.5958/2455-7145.2017.00011.X.

PACHEPSKY, Y.A.; RAWLS, W.J. Development of pedotransfer functions in soil hydrology. New York, Elsevier. 542 pp, 2004.

RAMOS, T. B., GONÇALVES, M. C., MARTINS, J. C., VAN GENUCHTEN, M. T.; PIRES, F. P. Estimation of soil hydraulic properties from numerical inversion of tension disk infiltrometer data. Vadose Zone Journal, v.5, p. 684-696, 2006. https://doi.org/10.2136/vzj2005.0076

RASHID, N. S. A., ASKARI, M., TANAKA, T., SIMUNEK, J.; VAN GENUCHTEN, M. T. Inverse estimation of soil hydraulic properties under oil palm trees. Geoderma, v. 241-242, p. 306-312, 2015. https://doi.org/10.1016/i.geoderma.2014.12.003

REYNOLDS, W. D.; ELRICK, D. Determination of hydraulic conductivity using a tension infiltrometer. Soil Science Society of America Journal, v. 55, p. 633-639, 1991. https://doi.org/10.2136/sssaj1991.036159950055000300 $\underline{01 x}$

REYNOLDS, W. D., BOWMAN, B. T., BRUNKE, R. R., DRURY, C. F.; TAN, C. S. Comparison of tension infiltrometer, pressure infiltrometer, and soil core estimates of saturated hydraulic conductivity. Soil Science Society of America Journal, v.64, p. 478-484, 2000. https://doi.org/10.2136/sssaj2000.642478x.

RIANNA, G., PAGANO, L.; URCIUOLI, G. Rainfall patterns triggering shallow flowslides in pyroclastic soils. Engineering Geology, v.174, p. 22-35, 2014. https://doi.org/10.1016/i.enggeo.2014.03.004

ROMANO, N., HOPMANS, J.W.; DANE, J.H. Methods of soil analysis. Part 4: Physical methods. In: DANE, J.H.; TOPP, G.C (eds). Methods of soil analysis. SSSA Book Ser. 5. SSSA, Madison, WI. p. 692-698, 2002.

SCHAAP, M. G., LEIJ, F. J.; VAN GENUCHTEN, M. T. Rosetta: a computer program for estimating soil hydraulic parameters with hierarchical pedotransfer functions. Journal of Hydrology, v.251, n. 3-4, p.163-176, 2001. https://doi.org/10.1016/S0022-1694(01)00466-8

SHEIN, E.V., MADY, A.; MOHAMED, E.A. Soil saturated hydraulic conductivity assessment by direct and pedotransfer functions methods. Biogeosystem Technique, v.6, n.4, p. 396-400, 2015. https://doi.org/10.13187/bgt.2015.6.396

SCHERGER, L.E., LEXOW, C., ZANELLO, V.; CARBAJO CASTOLDI, M. Salinização de solos de textura fina por ascensão capilar a partir do aquífero raso hipersalino (Bahía Blanca, Argentina). Águas Subterrâneas, v. 33, n. 2, p. 159-170, 2019. https://doi.org/10.14295/ras.v33i2.29265

SIMUNEK, J.; VAN GENUCHTEN, M. T. Estimating unsaturated soil hydraulic properties from multiple tension disc infiltrometer data. Soil Science, v.162, p. 383-398, 1997.

SIMUNEK, J., ANGULO-JARAMILLO, R., SCHAAP, M. S., VANDERVAERE, J.P.; VAN GENUCHTEN, M. T. Using an inverse method to estimate the hydraulic properties of crusted soils from tensiondisc infiltrometer data. Geoderma, v.86, p. 61-81, 1998. https://doi.org/10.1016/S0016-7061(98)00035-4

SIMUNEK, J., VAN GENUCHTEN, M. T.; SEJNA, M. The HYDRUS Software Package for Simulating the Two- and Three-Dimensional Movement of Water, Heat, and Multiple Solutes in VariablySaturated Porous Media, (Version 3.0). PC Progress, Prague, Czech Republic, 246p, 2018. https://www.pc-progress.com//Downloads/Pgm_Hydrus3D3/HYDRUS3D Technical_Manual_V3.pdf

VAN GENUCHTEN, M. T. A closed-form equation for predicting the hydraulic conductivity of unsaturated soils. Soil Science Society American Journal, v.44, p. 892-898, 1980. https://doi.org/10.2136/sssaj1980.036159950044000500 $\underline{02 x}$

VAN GENUCHTEN, M.T., LEIJ, F.J.; YATES, S.R. The RETC code for quantifying the hydraulic functions of unsaturated soils. Environmental Protection Agency (EPA), p. 1-93,1991. https://www.ars.usda.gov/ARSUserFiles/20360500/pdf_pubs/P1228.pdf

WATSON, K. W.; LUXMOORE, R. J. Estimating macroporosity in a forest watershed byuse of a tension infiltrometer. Soil Science Society of America Journal, v. 50, p. 578-582, 1986. https://doi.org/10.2136/sssaj1986.036159950050000300 $\underline{07 x}$.

WIND, G.P. Capillary conductivity data estimated by a simple method. In: RIJTEMA, P.E.; WASSINK , H. (eds.) Water in the unsaturated zone. Vol. 1. Proc. Wageningen Symp., Wageningen, Netherlands. p. 181-191, 1968.

WOODING, R. A. Steady infiltration from a shallow circular pond. Water Resources Research, v.4, n. 6, p. 1259-1273, 1968. https://doi.org/10.1029/WR004i006p01259

YAN, W.M.; ZHANG, G. Soil-water characteristics of compacted sandy and cemented soils with and without vegetation. Canadian Geotechnical Journal, v.52, n. 9, p.1331-1344, 2015. https://doi.org/10.1139/cgj-2014-0334

ZHANG, F.Z. Field soil water retention of the prototype hanford barrier and its variability with space and time. Vadose Zone Journal, v14, n.8, p.1-10, 2015. http://dx.doi.org/10.2136/vzj2015.01.0011 